\title{
CONSTRUCTION OF GIFTS "TO A AND HIS CHILDREN" (HEREIN THE RULE IN WILD'S CASE)*
}

\author{
A. JaMIES CASNer $\dagger$
}

I. INTRODUCTION

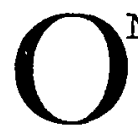

NE OF the prized incidents of the institution of private property is the power of the owner over the devolution of his title. Yet, the careless way in which this power frequently is exercised makes one doubt whether it is appreciated. If the intention of the owner as to the choice of his successors in interest is so inadequately expressed that the courts are compelled to engage in a guessing contest to determine his intention, the exercise of this power by the owner becomes a mere matter of chance.

The situations in which the most trouble arises are those where the beneficiaries of a disposition are described not by their individual names, but with reference to their membership in some group such as "children," "heirs," etc. The ambiguities inherent in these group descriptions are obviously not apparent to many persons who draft instruments using these phrases or far more care would be taken to avoid the disputes which are constantly arising.

This article is concerned with the problems raised by one of these stock phrases frequently used to describe beneficiaries, namely, "A and his children." Anyone fully conscious of the dynamite in those simple words would, I am sure, never use them. But since they have been and continue to be used rather widely, an awakening seems to be essential and that is the principal purpose of this discussion.

When the beneficiaries of a disposition are described by the phrase " $\mathrm{A}$ and his children," or some other equally incomplete expression, the technique employed by the courts to solve the disputes which arise is to adopt rules of construction which are to control in the absence of appropriate evidence manifesting some other desire. These rules of construction are designed to give effect to what the transferor probably would have intended had he thought about the problem which faces the court. Whether

* The author wishes to acknowledge his indebtedness to his colleagues, Professors Gardner and Scott, who read this article and contributed valuable suggestions.

$\dagger$ Assistant Professor of Law, Harvard University Law School. 
they accomplish this objective is highly debatable in many instances, especially in connection with the phrase under discussion. But aside from that, since the evidence that may negative the rules of construction is as varied as the weather, they are absolutely unreliable as guides to the draftsman. This is true whether the rule of construction is formulated by the court or by a statute. The draftsman's only course is to express completely in clear and unambiguous language the exact desires of his client.

In the material which follows, the various rules of construction applicable to gifts to a parent and his children are discussed and the situations which overcome their applicability are noted. Then we are in a position, having noticed the traps which have ensnared others, to plan to avoid them in the future. Thus, the concluding portion of this article is devoted to a comment on draftsmanship when a parent and his children are the intended objects of one's beneficence.

\section{FIRST RESOLUTION IN WILD'S CASE AND THE EXTENT OF ITS APPLICATION IN THE UNITED STATES}

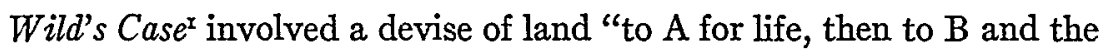
heirs of his body, then to $C$ and his wife, $D$, and after their decease to their children." At the time the devise was made $C$ and $D$ had a son and a daughter. The testator died, then $B$ died without heirs of the body. Prior to B's death, C and D had died and their son had also died (what became of their daughter does not appear). The son, however, left surviving a daughter. This daughter claimed the subject matter of the devise. The basis of her claim was that $\mathrm{C}$ and his wife, $\mathrm{D}$, acquired by the devise an estate tail which descended on their death to their son's daughter, the claimant. The only other construction possible under the language of the devise was that $\mathrm{C}$ and $\mathrm{D}$ acquired an estate for their lives and their children took by purchase under the limitation in their favor. This construction, however, would defeat the claim of the son's daughter because the son would acquire only a life estate under the limitation to "children" since there were neither words of inheritance nor any manifestation of intention to create a fee simple estate in the children. One or the other of these things was essential at the time of Wild's Case to create a fee simple estate by devise. If the son acquired only a life estate, of course, there was nothing to pass on his death to his daughter. The court held that the children of $C$ and $D$ took by purchase a remainder for life under the terms of the devise; and thus the claimant, the son's daughter, received nothing.

× 6 Co. $16 \mathrm{~b}$ (K.B. I599). 
In the course of the opinion the court promulgated what is known as the first resolution in Wild's Case. It is as follows: "If A devises his lands to $B$ and to his children or issues, and he hath not any issue at the time of the devise, that the same is an estate tail." This resolution was purely dictum, because the facts in Wild's Case were entirely different from the facts supposed for the purpose of the resolution. Nevertheless, this resolution has received sufficient notoriety to require a careful study of it to determine to what extent it controls the meaning of a gift to a named person and his children.

At the time Wild's Case was decided, there was ample justification for the conclusion stated on the basis of the facts supposed in the first resolution. A devise of land "to A and his children" clearly showed an intention on the part of the testator to have the children of A share in the disposition if any should be born. This objective could have been accomplished in several ways when the situation was that $A$ had no children at the date of the devise. First, the words "and his children" could be construed as words of limitation, descriptive of an estate in A which might descend to the children or some of them. Second, A might be given an estate for life with a remainder in his children, also for life, because of the absence of words of inheritance or of words manifesting an intent to create in the children more than a life estate. Third, A could be allowed to take the devise subject to partial divestiture in favor of the children when and as born; A and the children born acquiring proportionate life estates only, because of the absence of any appropriate designation of a larger estate. Of these possible constructions the first seems the most desirable in the light of circumstances then existing, because at least it creates an estate that has qualities of endurance beyond the lifetime of $\mathrm{A}$ and his children and, thus, might very well be of more lasting benefit. If the words "and his children" are to be considered words of limitation, they are much more like the words "heirs of the body" than the word "heirs," and, thus, the adoption of the first possible construction naturally leads to the conclusion stated in the first resolution in Wild's Case-that an estate in fee tail is created.

The first resolution in Wild's Case as stated above sets forth the following requirements for its application:

r. The transfer must be by a devise;

2. The subject matter of the devise must be land;

3. The form of the devise must be "to A and his children" or "to A and his issue";

4. The named person must have no children at the date of the devise. 
When these requirements are satisfied, a number of courts, both in this country and in England, have held that a fee tail estate (or an estate in fee simple conditional where the statute of $D e$ Donis is not in force) is created in the named person. ${ }^{2}$ After the estate in fee tail is created by the application of the first resolution in Wild's Case, the local statute on entails operates on the estate and, as a consequence, the designated person frequently ends up with a fee simple estate. ${ }^{3}$

Though the local law changes fee tail estates into fee simple estates, the ultimate result is not necessarily the same as would be reached if the first resolution in Wild's Case were abolished. It is true that in the case of immediate devises "to A and his children," when A has no children at the date of the devise, A could be given a fee simple estate directly under modern statutes creating a presumption in favor of such estates, but the presence of the word "children" might very well throw sufficient doubt on the meaning of the devise to justify the construction that $A$ is to have a life estate with a remainder in the children, or that $A$ is to take the estate subject to partial divestiture in favor of the children when and as born. If the

$=$ Local stahute converted estate in fee tail into an estate in fee simple: Gilchrist v. Butler, $2 \mathrm{I}_{4}$ Ala. 288, 107 So. 838 (I926); Wiley, Parish \& Co. v. Smith, 3 Ga. 55I (I847); Butler v. Ralston, 69 Ga. 485 (I882); Moore v. Gary, 149 Ind. 5I, 48 N.E. 630 (r897); Silliman v. Whitaker, II9 N.C. 89,25 S.E. 742 (I896); Elkins v. Seigler, 154 N.C. 374 , 70 S.E. 636 (Igrr); Cole v. Thornton, 180 N.C. 90 , I04 S.E. 74 (1920); Masters v. Randolph, 183 N.C. 3 , IIo S.E. 598 (I922); Ziegler v. Love, I85 N.C. 40, II 5 S.E. 887 (I923); Kendall v. Eyre, 22 Va. 288 (I823); Larew v.Larew, 146 Va. I34, I35 S.E. 8I9 (I926); Lofton v. Murchison, 80 Ga. 391, 7 S.E. 322 (1888) (subject to an executory limitation). Owner of estate in fee tail has power to convey an estate in fee simple: Parkman v. Bowdoin, Fed. Cas. No. $1076_{3}$ (C.C. Mass. 8 $_{33}$ ); Nightingale v. Burrell, 32 Mass. I04 (1833) (power exercised); Seibert v. Wise, $70 \mathrm{~Pa}$. I47 (187r) (power exercised); Harkness v. Corning, 24 Ohio St. $4^{I 6}$ (I873) (remained an estate in fee tail for the lifetime of the first donee); Simpson v. Antley, I37 S.C. 380, x35 S.E. 469 (r926) (estate in fee simple conditional created, and on birth of issue a power to convey an estate in fee simple absolute arose). Miscellaneous: Davie v. Stevens, I Doug. 321 (K.B. r780); Seale v. Barter, 2 Bos. \& P. 485 (C.P. I80I); Broadhurst v. Morris, 2 B. \& Adol. I (K.B. I831); Parking v. Knight, ${ }_{5} \mathrm{Sim} .83$ (Ch. 1846); Clifford v. Koe, 5 App. Cas. 447 (1880); In re Smith \& Love, 18 Ont. W.N. I8r (xg20); cf. Shuttle \& Weaver Land \& Improvement Co. v. Barker, I78 Ala. 366, 60 So. 557 (I912); Guy v. Pruitt, 213 Ala. 422, x04 So. 805 (I925); Moore v. Ennis, Io Del. Ch. 170, 87 Atl. 1009 (Igr3); Wheatland v. Dodge, Io Metc. (Mass.) 502 (I845); Chrystie v. Phyfe, I9 N.Y. 344 (I859); Hilliker v. Bart, 64 App. Div. 552, 72 N.Y. Supp. 301 (IgOI); Atkinson v. McCormick, 76 Va. 79 I (I882); Martin v. Martin, 52 W. Va. 38I, 44 S.E. 198 (1903); Rooke v. Queen's Hospital, I2 Hawaii 375 (I900); Butler v. Lowe, 10 Sim. 317 (Ch. 1839). The above cases frequently involved trusts, thus indicating that the courts have not adhered to the suggestion in Turner v. Ivie, 52 Tenn. 222 (I87I) that the first resolution in Wild's Case does not apply when the gift to the parent and children is in trust.

3 Cases cited in note 2 supra. For a collection of the statutes on estates in fee tail, see I Rest., Property c. 5, Introductory Note, Special Notes I-6 (I936). 
gift "to A and his children" is postponed, as will be seen later, the first resolution may apply if $A$ has no children at the date of the devise, and its application plus the operation of the local law on entails, would give A immediately a vested remainder in fee simple; whereas the repudiation of the first resolution would always cause A's interest in remainder to be subject to partial divestiture by the birth of children during the postponed period. In any jurisdiction where the local law as to entails converts what was a fee tail estate at common law into a life estate in the first taker with a remainder in the heirs of his body, the ultimate result of the application of the first resolution may obviously be different from the result that might be reached if the first resolution were repudiated.

Form of the devise. - The form the devise must take to subject it to the first resolution in Wild's Case is "to A and his children" or "to A and his issue." Thus, a devise "to A for life and then to his children" or "to A for life then to his issue" is entirely outside the scope of the resolution. ${ }^{4}$ Likewise, the employment of the traditional formula for creating an estate in fee simple, that is, "to A and his heirs," does not make applicable the first resolution unless the context indicates that the word "heirs" is used as meaning children in the limitation..$^{5}$ Furthermore a devise "to A and the heirs of his body" created a fee tail estate without the aid of the first resolution and so there is no need to rely on it in such cases unless the evidence discloses that the words "heirs of the body" mean "children."

Other phrases have been deemed the equivalent of the words " $A$ and his children" or "A and his issue." The following are examples of equivalent phrases which are sufficient to invoke the first resolution: "To A free and clear of the control of her husband to be enjoyed by her and her children"; 7 "to $A$ and his lawful issue him surviving forever"; "to A and her children

4 Wild's Case itself is authority for the proposition that the first resolution does not apply to a gift to the parent for life, then to his children. See also Lessee of Miller v. Hunt, I2 Ga. 357 (I852); Conover v. Cade, 184 Ind. 604, Ir2 N.E. 7 (I9I5); Cannon v. Barry, 59 Mass. 289 (I88I); Cote v. Von Bonnhorst, 4I Pa. St. 243 (I86I); Taylor v. Taylor, 63 Pa. 48I (I870); Grant v. Fuller, 33 Can. S. C. 34 (Ig02); In re Beckstead, [I928] 4 D. I. R. 666 (Ont. S.C.). But cf. In re Smith \& Love, I8 Ont. W.N. I8I (I920), in which case the court applied the first resolution in Wild's Case to a devise "to $A$ and at his decease to his surviving children as he may devise." In Rooke v. Queen's Hospital, I2 Hawaii 375 (xg0o), the court seemed to think the first resolution in Wild's Case applied to a limitation "to A to be used and enjoyed by her during the term of her natural life and her children forever."

5 Daniel v. Bass, 193 N.C. 294 , ${ }_{3} 6$ S.E. 733 (r927). Casner, Construction of Gifts to Heirs and the Like, 53 Harv. L. Rev. 207 (1939).

${ }^{6}$ But cf. State ex rel. Farley v. Welch, $x_{75}$ Mo. App. 303, x62 S.W. 637 (1913).

7 Butler v. Ralston, 69 Ga. 485 (I882); Lofton v. Murchison, 80 Ga. 39 I, 7 S.E. 322 (I888).

8 Hilliker v. Bart, 64 App. Div. 552, 79 N.Y. Supp. 30 I (I $9 \circ$ I). 
if any";" "to A and all her children if she shall have any"; "xo "to A and his children forever"; ir "to A and his children lawfully to be begotten"; "r2 "to $A$ and his children but if he dies without having a child or children then to B." "13

The literal language of the first resolution in Wild's Case would seem to confine the resolution to gifts which in form purport to set up an immediate estate in the parent and his children. The interpretation of the resolution, however, has been to apply it to gifts "to A and his children" and the like whether the same are immediate or postponed. Thus, a devise of land "to A for life, then to B and his children" creates a remainder in fee tail in B if he has no children at the date of the devise. ${ }^{14}$ Likewise, the fact that the devise is in trust for "A and his children" does not prevent the application of the first resolution. ${ }^{\mathrm{IS}}$

No children at the date of the devise.-The requirement for the application of the first resolution that there be no children at the date of the devise is capable of two interpretations. First, it may mean that there must be no children at the date the will is executed. Second, it may mean that there must be no children at the date the will takes effect. The first interpretation seems to have been adopted in England, ${ }^{16}$ though in one English case ${ }^{x 7}$ where no child was born at the time the will was executed, but one was born before the will took effect and the named parent died before the testator, the child was allowed to take under the terms of the will. If the first resolution had been applied, the named person would have tak-

${ }^{9}$ Cole v. Thornton, 180 N.C. 90, x04 S.E. 74 (I920).

so Silliman v. Whitaker, $1 \times 9$ N.C. 89,25 S.E. 742 (1896).

II Parkman v. Bowdoin, Fed. Cas. No. Io763 (C.C. Mass. I833); Davie v. Stevens, I Doug. 32I (K.B. I780); Broadhurst v. Morris, 2 B. \& Adol. r (K.B. I83I).

${ }^{x 2}$ Seale v. Barter, 2 Bos. \& P. 485 (C.P. I8or).

${ }_{23}$ Wiley, Parish \& Co. v. Smith, 3 Ga. 55I (I847); Moore v. Gary, 149 Ind. 5I, 48 N.E. 630 ( 1897 ); Elkins v. Seigler, 154 N.C. 374,70 S.E. 636 (19II).

${ }^{14}$ Parkman v. Bowdoin, Fed. Cas. No. 10763 (C.C. Mass. 1833 ); Butler v. Ralston, 69 Ga. 485 (1882); Moore v. Gary, 149 Ind. 5r, 48 N.E. 630 (1897); Elkins v. Seigler, 154 N.C. 374 , 70 S.E. 636 (I9II); Cole v. Thornton, I80 N.C. 90, I04 S.E. 74 (r920); Ziegler v. Love, 185 N.C. 40, II5 S.E. 887 (1923); Simpson v. Antley, I37 S.C. 380, I35 S.E. 469 (1926); Broadhurst v. Morris, 2 B. \& Adol. I (K.B. I83I); see Rooke v. Queen's Hospital, I2 Hawaii 375 (I900).

${ }^{x s}$ Many of the cases cited in note 2 supra involve trusts. But cf. Turner v. Ivie, 52 Tenn. $222(\mathrm{I} 87 \mathrm{I})$.

${ }^{26}$ Seale v. Barter, 2 Bos. \& P. 485 (C.P. 180r).

${ }^{27}$ Buffer v. Bradford, 2 Atk. 220 (Ch. I74I). Byng v. Byng, Io H.L. Cas. I7I (I862), explains Buffer v. Bradford on the ground that the testator's manifested intention prevented the application of the Rule in Wild's Case. 
en an estate in fee tail which would have lapsed by virtue of his death before the testator.

The second interpretation seems to be more sensible even when viewed in the light of the historical considerations which prompted the formulation of the resolution. If the object is to give a construction which would enable the children, or some of them, to share in the disposition, that is accomplished by allowing the children born before the death of the testator to take directly. Also, the second interpretation cuts down the frequency of the operation of the resolution, a result which is desirable since a somewhat artificial meaning is being assigned to the words used and since the popularity of estates in fee tail has dwindled considerably in modern times. The American courts, moved by these considerations or others, have picked the date the will takes effect as the crucial date for determining whether there are children. ${ }^{x 8}$

When the gift to the parent and his children is postponed to some period subsequent to the testator's death, an argument can be made that the crucial date at which there must be no children is the end of the postponed period. The basis of this argument is that the children born after the testator and before the end of the postponed period would be available to take directly, and, therefore, there is no need to adopt a construction built up just to afford them an opportunity to share in the gift. The view that the crucial date is the death of the testator when the will takes effect has prevailed, however, even when a postponed gift is involved. The birth of children after the will takes effect and before the end of the postponed period does not affect the nature of the parent's estate. ${ }^{\text {I9 }}$

A child in gestation is considered as a child in being; and so if at the testator's death, the named person has no children born but one is in gestation who is later born alive, the first resolution is inapplicable."

When a devise of land is made "to A and her children," A may have only illegitimate children or adopted children at the death of the testator. Do such children count in determining the applicability of the first resolu-

${ }^{88}$ Wills v. Foltz, 6I W.Va. 262, 56 S.E. 473 (I907); see Nimmo v. Stewart, 21 Ala. 682 (1852); Heath v. Heath, II4 N.C. 547, I9 S.E. I55 (1894); Silliman v. Whitaker, II9 N.C. 89, 25 S.E. 742 (1896); cf. Wiley, Parish \& Co. v. Smith, 3 Ga. 55 I ( 1847 ). All that is required is that the child be in ventre sa mere at the time the testator dies; such child is the same as a child in being for this purpose. See note 20 infra.

${ }^{19}$ Ziegler v. Love, 185 N.C. 40, II5 S.E. 887 (I923); see Parkman v. Bowdoin, Fed. Cas. No. 10763 (C.C. Mass. I833); Vanzant v. Morris, 25 Ala. 285 (1854); Butler v. Ralston, 69 Ga. 485 (1882); Moore v. Gary, I49 Ind. 5I, 48 N.E. 63 ० (I897); Larew v. Larew, I46 Va. 134, I35 S.E. 8rg (rg26); Broadhurst v. Morris, 2 B. \& Adol. I (K.B. $x 83$ r).

${ }^{20}$ Biggs v. McCarty, 86 Ind. 352 (1882); see Heath v. Heath, II4 N.C. 547 , 19 S.E. I55 (I894). 
tion? If they are entitled to take as purchasers under a devise to the children of a person other than the testator, then the requirement that there be no children at the testator's death is not satisfied. But if they are excluded as purchasers from such gifts, the situation is the same as though they never existed and the first resolution is applicable. ${ }^{2 x}$

The view that the significant date is when the will takes effect presents one problem which, though it has not been the subject of litigation as yet, should be discussed at this point. Suppose a devise of land is made "to A and his children" and A either has children at the date the will is executed or some are born before the testator dies but all his children die before the testator, so that at the date the will takes effect he has no children. Does the first resolution apply? If the first resolution is applicable, so that A acquires an estate in fee tail, there cannot possibly be any lapse, and consequently, no interest can pass under any lapse statute. If the fact that $\mathrm{A}$ at one time had children is enough to prevent the applicability of the first resolution, then two solutions are possible.

First, $\mathrm{A}$ and his children can be treated as a class, so that the parent as the survivor of the class becomes entitled to the entire subject matter of the gift, and today he would take an estate in fee simple as the survivor under the statutes which create a presumption in favor of such estates. $^{22}$ If, however, there is a lapse statute applicable to class gifts and it is satisfied both as to the relationship required between the testator and the deceased beneficiary and as to the relationship required between the deceased beneficiary and those who are available to represent him, the interests of the deceased children would pass in accordance with the terms of the lapse statute. ${ }^{23}$

Second, A may not be regarded as a member of a class composed of himself and his children, so that the portion of the gift which would have passed to his children if they had lived lapses in the absence of an applicable lapse statute.

${ }^{2 x}$ Rest., Property §§ 286-7 (Tent. Draft no. Ix 1939). In Shearman v. Angel, 8 S.C. Eq. $35 \mathrm{r}(\mathrm{r} 83 \mathrm{I})$, the subject matter of the disposition was personalty and the named parent took all of it when the only children she had were illegitimate; to the same effect is Doggett v. Moseley, 52 N.C. 587 (1860).

${ }_{22}$ For a collection of the statutes which eliminate the necessity of words of inheritance or of any other manifestation of an intention to create an estate in fee simple in a devise of land, see I Rest., Property \& 39, Special Note (1936). In Davis v. Sanders, I23 Ga. I77, 5 I S.E. 298 (I905), the subject matter of the gift was personalty and the named parent took the entire subject matter of the gift absolutely when all the children died before the testator; to the same effect is Mason v. Clarke, I7 Beav. I26 (Rolls Ct. I853).

${ }^{23}$ For a collection of lapse statutes and a discussion of their applicability to class gifts, see Rest., Property \& 298 Comment (c), Special Notes I-6 (Tent. Draft no. II 1939). 
The proper view in a jurisdiction that is committed to the first resolution in Wild's Case would seem to be to apply the first resolution whenever there are no representatives of children capable of taking under an appropriate lapse statute at the date the will takes effect. In this way, the prevention of a lapse would be assured, and the chance of children later born sharing in the gift would be preserved to the fullest extent possible.

One final problem is left in connection with the meaning of the requirement that there be no children at the date the will takes effect. This is illustrated by the case of Wheatland $v$. Dodge, ${ }^{24}$ where the devise was "to A and his children or grandchildren" and A had children at the testator's death but had no grandchildren at that time. The court held that the first resolution was applicable because there were no grandchildren in being when the will took effect. Other factors in the case which were mentioned by the court probably justified the conclusion that $\mathrm{A}$ received an estate tail by the devise, but to base this result on the first resolution in Wild's Case seems to be entirely unwarranted.

Rule of construction or rule of law.-The first resolution in Wild's Case as it is worded appears to be a rule of law because no exception to its applicability is noted once the specified requirements are satisfied. The courts in applying it, however, have treated it as a rule of construction only. The presence of additional factors which indicate that the interest of the named parent is to be other than an estate in fee tail is respected and given effect. The evidence present may justify the conclusion that in the gift "to A and his children" the word "children" was used as a word of limitation, synonymous with the word "heirs," in which case the named person takes directly an estate in fee simple..$^{25}$ More frequently the additional evidence justifies the conclusion that the testator intended to create an estate for life in the parent and a remainder in the children. ${ }^{26}$

24 Io Metc. (Mass.) 502 (I845).

${ }^{25}$ Moushand v. Rodetzky, 5 Ohio N.P. 256 ( 1898 ) (gift was "to A and her children and grandchildren" and the court concluded that by virtue of the reference to grandchildren the testator was really attempting to describe heirs generally).

${ }^{26}$ Sisson v. Seabury, Fed. Cas. No. I2913 (C.C. R.I. I832) (the devise was "to A and his children and their heirs forever," and the court decided that the words "their heirs forever" showed an intention to create a fee simple estate in the children, and so they gave the parent a life estate only); Conover v. Cade, I84 Ind. 604, XI2 N.E. 7 (I9I6) (the devise read "to A and when he is done with it, to his children," and the court said this language showed an intent to create only a life estate in A); Dougherty v. Dougherty, 2I S.C. Eq. 63 (1848) (devise of residue "to $A$ and her children, if she leaves any at her death"); Martin v. Martin, 52 W.Va. 38x, 44 S.E. I98 (1903) (after the gift "to A and his children" was a proviso that if A "died without children" the gift should go to another, and the court held that the provision for a gift over on death without "children" negatived the idea of a fee tail estate; one judge held that a life estate in the parent with a remainder in the children was created); In re Jones [rgro] I Ch. 167 
In Mitchell v. Lang, ${ }^{27}$ the gift was "to A, to him, his wife and children during their natural lives if he shall ever have any and if not he shall have it all himself." Since the gifts to each of the designated beneficiaries were confined to their lives, no greater estate than an estate for life could be created. The court held that A took the entire subject matter of the gift subject to partial divestiture when and as the children were born. Thus, the literal language of the gift was given complete effect.

Since the first resolution is subject to control by evidence which indicates the testator did not intend to create an estate in fee tail, some attention should be paid to those factors which are insufficient to overcome the resolution and to those factors which tend to support the conclusion reached by the application of the resolution. Thus, the fact that the named parent has a power to appoint a fee simple estate,,$^{28}$ or that the estate of the named parent is free and clear of the control of her husband, ${ }^{29}$ are not considered inconsistent with the creation of an estate in fee tail in the parent. On the other hand, if the gift specifically provides for a gift over if the parent "dies without issue," that is said to support a holding for an estate in fee tail..$^{30}$

\section{FIRST RESOLUTION IN WILD'S CASE REPUDIATED AND THE EFFECT OF ITS REPUDIATION}

There is little or no justification for the continuance in modern times of the rule of construction promulgated in the first resolution in Wild's Case. Any doctrine which today creates a presumption that a testator intends to create an estate in fee tail is completely divorced from reality. In many states there are statutes which convert what would have been a fee tail estate at common law into some form of fee simple estate; ${ }^{3 x}$ and

(a gift over on "death without issue" held to show there was to be no division until the parent died and, therefore, the parent must have an estate for life and the children a remainder). Note 99 infra discusses the effect of a gift to several persons and their children when some have children and some do not. Consider also, State ex rel. Farley v. Welch, I75 Mo. App. 303, I62 S.W. 637 (Igr4); Turner v. Ivie, 52 Tenn. 222 (I87I).

${ }_{27} 80 \mathrm{~Pa} .516$ (1877).

${ }^{28}$ Seale v. Barter, 2 Bos. \& P. 485 (C.P. I8or); Clifford v. Koe, 5 App. Cas. 447 (I880); In re Smith \& Love, I8 Ont. W.N. I8I (rg20).

${ }^{29}$ Butler v. Ralston, 69 Ga. 485 (x882); Lofton v. Murchison, 80 Ga. 39I, 78 S.E. 322 (x888).

${ }^{30}$ Parkman v. Bowdoin, Fed. Cas. No. 10763 (C.C. Mass. 1833 ); Nightingale v. Burrell, 32 Mass. 104 (r833); Wheatland v. Dodge, ro Metc. (Mass.) 502 (r845); Ziegler v. Love, 185 N.C. 40, II 5 S.E. 887 (I923); Larew v. Larew, I46 Va. I34, I35 S.E. 8I9 (rg26); Broadhurst v. Morris, 2 B. \& Adol. I (K.B. I83I); Clifford v. Koe, 5 App. Cas. 447 (I880); cf. In re Jones, [19ro] I Ch. 167; Martin v. Martin, 52 W.Va. 38I, 44 S.E. I98 (Ig03).

${ }^{31}$ I Rest., Property c. 5, Introductory Note, Special Note 4 (1936). 
in many other states the fee tail estate is converted into a life estate in the first taker with a remainder in the heirs of the body..$^{32}$ Since almost everywhere some fundamental change has been effectuated in the nature of fee tail estates, their intentional creation today is very unlikely.

Furthermore, the objectives which caused the promulgation of the first resolution are today attainable to a greater extent in other ways. Any one of three constructions can be adopted today which will give the children, if any are born, an opportunity to share in the gift. First, the named parent can be given an estate in fee simple and the children, if any, will have a chance to take from him by descent. The estate in the parent would be considered a fee simple today because of the widespread adoption of statutes which set up a presumption that all devises are in fee simple unless a contrary intent is manifested..$^{33}$

Second, the parent can be given an estate in fee simple subject to partial divestiture when and as children are born, the children as born receiving a concurrent interest in fee simple.

Third, the parent can be given an estate for life with a remainder in fee simple in the children.

In the opinion of the writer the first solution is the least desirable of all. Oddly enough that is the result normally reached in states which continue to apply the first resolution in Wild's Case because the fee tail estate created is usually converted into an estate in fee simple by the local statute. ${ }^{34}$ The objection to the first solution is that it allows the parent to determine whether the children are to share in the gift. If the basic assumption is true that the testator, by mentioning the children, desired that if any were born they should share as purchasers, his intention should control and the matter of their sharing should not be left to the whim or caprice of the named parent.

Either of the other two constructions assures the children, if any, of a share in the property. Probably the third more nearly approximates what is likely to be the intention of the average testator because most people think of parent and children enjoying property successively and not concurrently. 35

Tlinois is an example of a state which has repudiated the first resolution and adopted in its place the first of the suggested solutions, that is,

${ }^{2}$ Ibid., Special Note 5 .

33 Ibid., § 39, Special Note.

34 Cases cited in note 2 supra.

35 The Restatement of the Law of Property has repudiated the first resolution in Wild's Case and adopted the life estate and remainder construction. Rest., Property $\$ 28_{3}$ (Tent. Draft no. II I939). The Uniform Property Act also adopts, in Section 13, the life estate and remainder construction. 
that the parent takes an estate in fee simple. ${ }^{36}$ In Illinois an estate in fee tail is converted by the local statute into an estate for life in the first taker with a remainder in the heirs of his body. ${ }^{37}$ Thus, the adoption of the first resolution in Wild's Case would result finally in the life estate and remainder construction after the local statute on entails had operated. The Tllinois Court argued that the purpose of the first resolution in Wild's Case was to enlarge what would have been a life estate in the parent into a fee tail estate, and in Illinois that purpose would be frustrated by the application of the first resolution because the local statute on entails would convert the resultant fee tail estate into a life estate in the parent with a remainder in the children. The fallacy of the view announced by the Illinois court is in its statement of the purpose of the first resolution. In mlinois, and states like it, ${ }^{38}$ where by statute fee tail estates are converted into a life estate in the parent and a remainder in the heirs of the body, the application of the first resolution really reaches the most desirable result.

No state in which the first resolution has been repudiated has adopted the second of the suggested solutions, that is, that the parent takes an estate in fee simple subject to partial divestiture when and as children are born. In Illinois, however, such result was reached in one case when the language of the gift was "to A and his children if any" on the ground that the words "if any" showed an intention to include after-born children. ${ }^{39}$ In Illinois, of course, if the gift to the parent and his children is postponed, the fee simple estate in the parent is subject to partial divestiture by the birth of children before the end of the postponed period. $4^{\circ}$

The third suggested solution, that the parent takes a life estate with a remainder in his children, has been adopted in several states in which the application of the first resolution in Wild's Case would have resulted in the creation of a fee simple estate because of the local statute on entails..$^{4}$

${ }^{36}$ Davis v. Ripley, I94 Ill. 399, 62 N.E. 852 (1902); Boehm v. Baldwin, 22 I Il. 59,77 N.E. 454 (1906) (after-born children included because the gift was to children "if any"); Reed v. Welborn, 253 Ill. $33^{8}, 99$ N.E. 669 (I9r2); Way v. Geiss, 280 Ill. I52, II7 N.E. 443 (I9I7) (gift postponed, and child born after the testator and before the end of the postponed period was allowed to share).

37 Mll. Rev. Stat. (1939), c. $30, \S 5$.

${ }^{38}$ For a collection of the statutes like the one in Illinois, see I Rest., Property c. 5, Introductory Note, Special Note 5 (I936). Consider also in this connection, Rooke v. Queen's Hospital, I2 Hawaii 375 (r900).

${ }^{39}$ Boehm v. Baldwin, 22 I Ill. 59, 77 N.E. 454 (Igo6).

${ }^{40}$ Way v. Geiss, 280 Ill. I 52, II 7 N.E. 443 (I9I7).

${ }_{41}$ Carr v. Estill, 55 Ky. 309 (I855); Righter v. Forrester, 64 Ky. 278 (I866) (the Kentucky court seems to be influenced by the fact that the life estate and remainder construction tends to keep the property in the blood of the testator, as for example, when the gift is to the testa- 
This view developed in Kentucky in connection with devises to the testator's wife and their children in order to assure the ultimate passage of the property to blood relatives of the testator, but now applies also in situations where the designated parent is a blood relative of the testator. In Pennsylvania the motivating factor was the desire to adopt a construction that would give the children more of a chance to share in the gift, now that the fee tail estate is completely under the control of the tenant in tail.

\section{DEEDS OF LAND AND PERSONALTY AND BEQUESTS OF PERSONALTY WHEN THERE ARE NO CHIIDREN}

The first resolution in Wild's Case as worded applies only to devises of land. Even aside from its wording, however, it could not possibly have any application to bequests of personalty or to deeds of realty or personalty. Estates in fee tail do not exist in personalty and that alone is enough to prevent the application to either bequests or deeds of personalty of a rule of construction that results in the creation of such an estate. ${ }^{42}$ In order to create an estate in fee tail by deed at common law the magic word "heirs" had to appear along with the words of procreation, and its absence in the limitations governed by the first resolution prevented the creation

tor's wife and her children); Oyster v. Knull, I37 Pa. 448, 20 Atl. 624 (I89o) (the language of the gift here seems to indicate the life estate and remainder construction); Chambers $\mathrm{v}$. Union Trust Co., 235 Pa. 6ro, 84 Atl. 512 (r9r2); In re Keown's Estate, 235 Pa. 343, 86 Atl. 270 (IgI3) (here the gift to the parent and his children was postponed); Turner v. Ivie, 52 Tenn. 222 (I87I); Buntin v. Plummer, I64 Tenn. 87, 46 S.W. (2d) 60 (1932); see Scruggs v. Mayberry, I35 Tenn. 586, I88 S.W. 207 (1916). In these states the wording of the gift must be observed very carefully because if it takes a form that would have resulted in the creation of a fee tail estate at common law independent of the first resolution in Wild's Case, it continues to have that effect, and the fee tail estate so created is converted into a fee simple estate: Lawson v. Todd, r29 Ky. r32, Iro S.W. 4I2 (rgo8) (deed); Wynne v. Wynne, $5^{6}$ Tenn. 308 ("to A and the issue of his body"); Scruggs v. Mayberry, I35 Tenn. 586, r88 S.W. 207 (I9I6) ("to A and the heirs of his body"). The presumption for a life estate and remainder construction may be overcome in these states by appropriate evidence: Wilson v. Morrill, $205 \mathrm{Ky} .257,265$ S.W. 774 ( 1924 ) (the gift was postponed and was "to A and his children forever" and the word "forever" was deemed sufficient to create a fee simple in A); Asper v. Stewart, $246 \mathrm{~Pa}$. 25r, 92 Atl. $\mathrm{r}_{33}$ ( $\mathrm{r}_{9} \mathrm{r}_{4}$ ) (devise of land "to A and her children, heirs, executors, administrators and assigns," and the court held that the coupling of the word "heirs" with the word "children" showed that the testator meant "heirs of the body," and so a fee tail estate was created which was converted into a fee simple estate under the local law). Cf. Williams v. Duncan, 92 Ky. 125 , 7 S.W. 330 (I89I).

In Ramey v. Ramey, I95 Ky. 673, 243 S.W. 934 (1922) a deed was involved and there were children at the date of the deed and the gift was "to $A$ and his children forever," and a life estate and remainder construction was adopted; to same effect is Hicks v. Jewett, $202 \mathrm{Ky} .6 \mathrm{r}$, 258 S.W. 934 (r924).

$4^{2}$ Challis, Real Property $6 x$ ( 3 d ed. $x 9 x$ ). In Vanzant v. Morris, 25 Ala. 285 ( 1854 ), there is an indication that the first resolution applied to a bequest of slaves, but at one time it was thought that an estate in fee tail could be created in slaves. 
of an estate in fee tail when a gift of land to a parent and his children was made by deed.43

When the subject matter of the disposition is personalty, a number of courts have concluded that the named parent takes it absolutely if there are no children at the date the dispositive instrument takes effect. ${ }^{44}$ This result has been influenced somewhat by the fact that a similar devise of land creates an estate in fee tail, and transfers of personal property which would create estates in fee tail as to land are thought to create absolute interests in personalty.

Some courts, on the other hand, have preferred the construction which gives to the named parent a life interest in the personal property with a remainder in his children. ${ }^{45}$ No court appears to have adopted a construction that would give the parent all the personalty subject to partial divestiture when and as children are born.

In one case ${ }^{46}$ there was a bequest of personalty to a parent and his children and there were children living at the date the will was drafted, but all the children died before the testator, so that at the date the will took effect there were no children living. Under these circumstances, the court treated the gift as one to a class composed of the parent and his children, and since the parent was the sole survivor of the class, he took the entire subject matter of the gift absolutely.

Deeds of land to a named person and his children when there are no children at the date the deed takes effect are rather rare in occurrence, especially if the gift is immediate. Today, in the light of the elimination

${ }^{43}$ Challis, Real Property 292 (3d ed. Igrr). But in James v. James, 189 S.C. $4{ }_{4} 4$, r S.E. (2d) 494 (1938), the court held that all the reasons which prompted the formulation of the first resolution in Wild's Case applied to a deed of land and, therefore, a deed "to A and his lawful children," A having no children at the date of the deed, presumptively created a fee simple conditional estate (South Carolina does not recognize the statute of De Donis, and so conveyances that would create fee tail estates elsewhere are estates in fee simple conditional). This result was reached even though words of inheritance were still necessary to create an estate in fee.

44 Gillespie v. Schuman, 62 Ga. $25^{2}$ (1879) (bequest); Doggett v. Moseley, 52 N.C. $5^{8} 7$, (1860) (bequest); Jenkins v. Hall, 57 N.C. 334 (1858) (bequest); Renwick v. Smith, II S.C. 294 (1877) (bequest); Pyne v. Franklin, 5 Sim. 458 (Ch. 1832) (bequest); Parkin v. Knight, I $_{5}$ Sim. 83 (Ch. I846) (bequest); cf. Guy v. Pruitt, 213 Ala. 422, Io4 So. 805 (I925); Davis v. Sanders, I23 Ga. I 77, 5 I S.E. 298 (Ig05); Shearman v. Angel, 8 S.C. Eq. 35 I (I83I); Johnson v. Johnson, I6 S.C. Eq. 345 (I842).

45 Furlow's Adm'r v. Merrell, 23 Ala. 705 (I853) (bequest); Williams v. McConico, $36 \mathrm{Ala}$. 22 (I860) (deed); Heron v. Stokes, 2 D. \& W. 89 (Ir. Ch. I842) (bequest); Audsley v. Horn, 26 Beav. I95 (Rolls Ct. I858) (bequest).

${ }^{46}$ Davis v. Sanders, I23 Ga. r77, 5I S.E. 298 (rgo5); to the same effect is Mason v. Clarke, r7 Beav. x26 (Rolls Ct. I853). 
of the necessity of the word "heirs" to create inheritable estates, the first resolution in Wild's Case could conceivably be extended to cover deeds of land so that the named person would receive an estate in fee tail on which the local statute on entails would operate. In a few states in which the local statute on entails converts estates in fee tail into estates in fee simple, the named person has been said to receive an estate in fee tail which the local statute converted into an estate in fee simple. ${ }^{47}$ If the ultimate result is to be that the named person has an estate in fee simple, the more sensible approach is to go there directly and not through the channel of first creating a fee tail estate. ${ }^{48}$

A few courts have preferred the construction that gives the named person a life estate in the land conveyed by deed with a remainder in his children.49 No courts, however, have given the named person an estate in fee simple subject to partial divestiture by the birth of children, and some cases even hold that such construction is impossible in connection with immediate gifts of land by deed because an unborn person cannot be the grantee of an immediate gift..$^{\circ 0}$ Why the named parent today cannot take subject to an executory limitation in favor of unborn children is difficult to understand.

If the gift to the named person and her children is postponed to some time subsequent to the date on which the dispositive instrument takes effect, children born prior to the end of the postponed period ought to be allowed to share even though the parent is given an absolute interest when the gift is immediate. We have seen that where the first resolution in Wild's Case is applied the failure to have children at the date the will takes effect settles the nature of the estate in the parent even though the gift is postponed. Since this resolution should not be applicable to bequests of personalty and deeds of realty and personalty, there is no reason to determine finally the nature of the parent's interest before the end of the postponed period..$^{\mathrm{I}}$

47 Davis v. Hollingsworth, II 3 Ga. 21o, 38 S.E. 824 (Igor); Boyd v. Campbell, I92 N.C. 398, 135 S.E. I21 (I926); see Dallas Compress Co. v. Smith, rgo Ala. 423, 67 So. 289 (Igr4); cf. James v. James, I89 S.C. 414, I S.E. (2d) 494 (1938), discussed in note 43 supra.

$4^{8}$ Consider Duffield v. Duffield, 268 MI. 29, Io8 N.E. 673 (I9r5).

49 Fales v. Currier, 55 N.H. 392 (1875); Baskett v. Sellars, 93 Ky. 2, 19 S.W. 9 (I892).

so Davis v. Hollingsworth, II3 Ga. 210, 38 S.E. 827 (rgor); Bank of Graymont v. Kingery, I70 Ga. 77I, 154 S.E. 355 (1930).

sx Consider Vanzant v. Morris, 24 Ala. 285 (I854). But in Scott v. Scott, I5 Sim. 47 (Ch. I845), there was a bequest of personalty "to A for life then to B and his children" and B had no children at the testator's death but some were born before the death of the life tenant, and $B$ was allowed to take absolutely and the children were excluded. Likewise, if the first resolution is deemed applicable to these dispositions as some courts have indicated, the children born before the end of the postponed period would be excluded. Notes 42,43 and 47 supra. 
Additional factors may, of course, cause the adoption of one or the other of the possible solutions discussed above. ${ }^{52}$ But what should be the preference in the absence of such enlightening additional factors? Here as suggested in connection with a devise of land to a person and his children when there are no children at the date the will takes effect, the average person probably thinks of parent and children enjoying property successively and not concurrently. If this is true, the preferred construction should be for a life interest in the parent with a remainder in his children. ${ }^{53}$

\section{SECOND RESOLUTION IN WILD'S CASE AND THE EXTENT OF ITS APPIICATION IN THE UNITED STATES}

The second resolution in Wild's Case is as follows: "If a man devises land to $A$ and to his children or issue, and they then have issue of their bodies . . . . they shall have but a joint estate for life." 54 This resolution adopts as the preferred construction, when there are children alive to share with the parent, the view that the parent and the children become concurrent owners of the property and not successive owners. The form of their concurrent ownership is a joint tenancy because of the constructional preference for joint tenancies which existed at the time of Wild's Case, , $^{55}$ and the duration of their joint tenancy is for life, again because of the necessity of the word "heirs" or some manifestation of intent to create more than a life estate at the time Wild's Case was decided..$^{56}$

The only requirement for the application of the second resolution which differs from the requirements for the application of the first resolution is with respect to the presence of members of the described group at the time of the devise. Both resolutions are confined to devises of land which take the form "to A and his children" or "to A and his issue"; but the first resolution applies when there are no children at the date of the devise and the second resolution applies when there are children at the date of the devise. The determination of the meaning of "at the date of the devise" must be the same for both resolutions or the two rules may conflict in part. Thus, the previous discussion as to the meaning of that phrase is applicable here. ${ }^{57}$

52 Life estate and remainder construction adopted because of the facts: Jennings v. Parker, ${ }_{24} \mathrm{Ga} .62 \mathrm{I}$ ( 1858 ) (bequest "to A personally, individually, exclusively, and to her children and not to her husband").

53 The following have adopted the life estate and remainder construction: Rest., Property $\S 283$ (Tent. Draft no. II I939); Uniform Property Act \& I3.

54 Wild's Case, 6 Co. $16 \mathrm{~b}$ (K.B. I599).

ss Digby, Real Property 280, n. I (5th ed. I897). See also, Oates v. Jackson, 2 Str. II72 (K.B. 1742).

${ }^{56}$ Digby, Real Property I65, n. I (5th ed. I897); Rest., Property $\$ 37$ (I936).

57 Notes I6-24 supra. 
The second resolution in Wild's Case has been widely recognized in the United States insofar as it holds that the parent and his children are to enjoy the land devised concurrently. ${ }^{58}$ Today, however, statutes have been widely adopted which create a presumption that all concurrent owners are to hold as tenants in common and not as joint tenants unless the intention that they hold as joint tenants is expressly manifested. These statutes generally have been applied to limitations coming within the second resolution in Wild's Case and have thus changed the nature of the concurrent ownership created in such cases. ${ }^{59}$ Likewise, the widespread abolition of the necessity of any words of inheritance to create a fee simple estate and the substitution in its place of the doctrine that all transfers are in fee simple unless a contrary intent is manifested has changed the concurrent ownership created from one for life to one in fee simple..$^{60}$

Form of the devise.-The form the devise must take to subject it to the second resolution is "to A and his children" or "to A and his issue." Thus, a devise "to A for life and then to his children" or "to A for life then to his issue" is entirely outside the scope of the resolution. ${ }^{6 r}$ If the devise takes

$5^{8}$ Kelly v. Kelly, $x 76$ Ark. 548, 3 S.W. (2d) 305 (I928); New England Mortgage Security Co. v. Gordon, 95 Ga. 78I, 22 S.E. 706 (1895); Whitfield v. Means, $x_{40}$ Ga. 430, 78 S.E. I067 (IgI3); Biggs v. McCarty, 86 Ind. 352 (I882); Noble v. Teeple, 58 Kan. 398, 49 Pac. 598 (1897); Allen v. Hoyt, 5 Metc. (Mass.) 324 (1842); Reddoch v. Williams, r29 Miss. 706, 92 So. 83 (I922); Hall v. Stephens, 65 Mo. 670 (I877); Kyte v. Kyte, 73 N.J. Eq. 220, 67 Atl. 933 (I907); Moore v. Leach, 50 N.C. *88 (I857); Hunt v. Satterwhite, 85 N.C. 73 (I881); Hampton v. Wheeler, 99 N.C. 222 (1888); Lewis v. Stancil, I54 N.C. 326,70 S.E. 621 (rgII); Benbury v. Butts, I84 N.C. 23, II3 S.E. 499 (I922); Snowden v. Snowden, I87 N.C. 539, I22 S.E. 300 (I924); Clark v. Clark, I3 Ohio App. I64 (I920); Smith v. Smith, ro8 Tenn. 2I, 64 S.W. 483 (Igor); Bently v. Ash, 59 W.Va. 64I, 53 S.E. 636 (Igo6); In re Gartland, I7 Ont. W.N. I47 (I9I9). In the following cases the subject matter of the devise consisted of both real and personal property or was a residuary devise without a clear indication as to the nature of the residue: Dryer v. Crawford, 90 Ala. x3I, 7 So. 445 (I889); In re Utz's Estate, 43 Cal. 200 (I872); Lord v. Moore, 20 Conn. I22 (1849); Talcott v. Talcott, 39 Conn. I86 (1872); Mitchell v. Mitchell, 73 Conn. 303, 47 Atl. 325 (I900); McCord v. Whitehead, 98 Ga. 38r, 25 S.E. 767 (I896); Gill v. Logan, 50 Ky. 23 I (I850); Annable v. Patch, 3 Pick. (Mass.) 360 (I825); Pruden v. Paxton, 79 N.C. 446 (I878); Coogler v. Crosby, 89 S.C. 508,72 S.E. 499 (I9II); Thomson v. Russell, I3I S.C. 529, I28 S.E. 42 (I925); Belote v. White, 39 Tenn. 703 (I859); Houston v. Schuhmann, 92 S.W. (2d) Io86 (Tex. Civ. App. x936); Fitzpatrick v. Fitzpatrick, xoo Va. 552, 42 S.E. 306 (Ig02); Wills v. Foltz, 6I W.Va. 262, 56 S.E. 473 (Ig07); Shaw v. Thomas, Ig Grant Ch. 489 (Ont. 1872 ). In Conner v. Everhart, I60 Va. 544 , 169 S.E. 857 (I933), real estate was placed in trust and income therefrom was given to the wife of the testator's son and her children until the death of the son, and they took the same concurrently.

59 Cases cited in note 58 supra. Contra: Noble v. Teeple, 58 Kan. 398,49 Pac. 598 (I897) (in this case the parent and the children took as joint tenants even though there was a local statute which created a presumption in favor of tenancies in common).

${ }^{60}$ Cases cited in note 58 supra, and I Rest., Property § 39, Special Note (1936).

6x Note 4 supra, and Casner, Class Gifts to Others than to "Heirs" or "Next of Kin"Increase in the Class Membership, $5^{x}$ Harv. L. Rev. 254,276 n. 55 (I937). 
the form "A and the heirs of his body," which would have created a fee tail estate directly at common law, the second resolution, of course, is inapplicable and the estate created by such language today depends on the local law as to estates tail. ${ }^{62}$

Other phrases have been deemed the equivalent of the words " $A$ and his children" or "A and his issue." The following are examples of equivalent phrases which are sufficient to invoke the second resolution: "To A free and clear of her husband's control and her children"; $6_{3}$ "to A, to her and her children";64 "to A and her children now living or hereafter born";65 "to A and the children born of her body";6 "to A for herself and her children"; "67 "to A and her children forever"; 68 "to A and her children to be divided among them according to law";"69 "to $A$ and to her children and to her children's children"; ;0 "to A, children, her heirs and assigns"; $7 \mathrm{x}$ "to $\mathrm{A}$ and her children in equal shares"; "to $\mathrm{A}$ and his issue but if he dies without issue," then over. ${ }^{73}$

In Virginia in a series of cases the court has considered the meaning of a disposition to a woman and her children, and the statement has appeared that such dispositions are to the woman absolutely, and the reference to her children simply indicates the motive for the gift. In all the cases in Virginia, however, where the woman has been given an absolute

62 Davis v. Stevens, I24 S.W. (2d) II32 (Mo. I939).

${ }^{63}$ New England Mortgage Security Co. v. Gordon, 95 Ga. 78r, 22 S.E. 706 (I895); McCord v. Whitehead, 98 Ga. 38 I, 25 S.E. 767 (I896).

64 Whitfield v. Means, I40 Ga. 430, 78 S.E. I067 (r9r3). But cf. Echols v. Jordan, 39 Ala. 24 (I863) (personalty involved); Hannan v. Osborn, 4 Paige (N.Y.) 336 (I834); Bowers v. Bowers, 4 Heisk. (Tenn.) 293 ( $187 \mathrm{I}$ ).

${ }_{65}$ Reddoch v. Williams, I29 Miss. 706, 92 So. 83I (I922); Belote v. White, 39 Tenn. 703 (1859); Houston v. Schuhmann, 92 S.W. (2d) ro86 (Tex. Civ. App. I936); Oates v. Jackson, 2 Str. Ir72 (I742). But cf. Downes v. Long, 79 Md. 382, 29 Atl. 827 (1894); Kinney v. Mathews, 69 Mo. 520 (1879) (deed).

${ }^{66}$ Annable v. Patch, 3 Pick. (Mass.) 360 (1825).

${ }^{67}$ Kyte v. Kyte, 73 N.J. Eq. 220, 67 Atl. 933 (xg07); Clark v. Clark, 13 Ohio App. I64 (rg20). But cf. Desmond v. MaciNeill, go Conn. I42, 96 Atl. 924 (I9I6); Conrad v. Conrad's Exec'r, I23 Va. 7 II, 97 S.E. 336 (19I8) (personalty).

${ }^{68}$ Moore v. Leach, 50 N.C. 88 (I857); cf. Moore v. Lee, I05 Ala. 435 , I7 So. I5 (1894) (deed); Cullens v. Cullens, I6I N.C. 344,77 S.E. 228 (IgI3) (deed); Naville v. American Machine Co., I45 Ky. 344, I40 S.W. 559 (I9II); Eakins v. Eakins, I9I Ky. 6I, 229 S.W. I3O (I921).

69 Pruden v. Paxton, 79 N.C. 446 ( 1878 ).

70 Benbury v. Butts, I84 N.C. 23 , II3 S.E. 499 (I922).

${ }_{73}$ Snowden v. Snowden, 187 N.C. 539 , I22 S.E. 300 (1924).

${ }^{72}$ Smith v. Smith, I08 Tenn. 2I, 64 S.W. 483 (IgOI).

73 Cormack v. Copous, I7 Beav. 397 (Rolls Ct. I853). 
interest, additional evidence is present to justify such conclusion..$^{74}$ When there is no such additional evidence the woman and her children take concurrently. ${ }^{75}$

The literal language of the second resolution would seem to confine the resolution to gifts which in form purport to set up an immediate estate in the parent and his children. The interpretation of the resolution, however, has been to apply it to gifts "to A and his children" and the like, whether the same are immediate or postponed. Thus, a devise of land "to A for life then to B and his children" creates a concurrent estate in remainder in the parent and his children if there are children alive at the date of the devise, and the gift is not confined to children alive at the date of the devise, but also includes those born prior to the end of the postponed period. ${ }^{76}$

Rule of construction or a rule of law.-The second resolution in Wild's Case, like the first, is only a rule of construction to be applied in the absence of additional factors that indicate the testator intended some other result. Sometimes the additional factors indicate that the word "children" is a word of limitation synonymous with the word "heirs" so that an estate in fee simple is created in the named person. ${ }^{77}$ More frequently the additional factors justify a conclusion that the named person is to receive only an estate for life with a remainder in his children. ${ }^{78}$

${ }_{74}$ Payne v. Kennay, I5I Va. 472, I45 S.E. 300 (I928) and the cases discussed therein.

75 Conner v. Everhart, 160 Va. 544 , т69 S.E. 857 (I933).

${ }^{76}$ Mitchell v. Mitchell, 73 Conn. 303,47 Atl. 325 (Ig00); Annable v. Patch, 3 Pick. (Mass.) 360 (1825); Hampton v. Wheeler, 99 N.C. 222 (1887); Benbury v. Butts, I84 N.C. 23 , II3 S.E 499 (I922); Smith v. Smith, 108 Tenn. 2x, 64 S.W. 483 (xgor); Oates v. Jackson, 2 Str. II72 (K.B. I742); Cormack v. Copous, I7 Beav. 397 (Rolls Ct. I853).

77 Connor v. Gardiner, 230 Ill. 258,82 N.E. 640 (rgo7) (necessary to give the named person an estate in fee simple in order to carry out the general plan of the testator); Halpin v. Cooke, 2I Pa. Co. III (I897) (devise was "to A to descend to his wife and children"); Vaughan v. Vaughan, 97 Va. 322, 33 S.E. 603 ( 1899 ) (intention found from general plan set out in will); Payne v. Kennay, I5I Va. 472, I45 S.E. 300 (I928) (same as Connor v. Gardiner supra). In Byng v. Byng, Io H.L. Cas. I7 $x$ ( 1862 ), the word "children" was construed to mean "heirs of the body" so that a fee tail estate was created even though there were children. In Wood v. Baron, I East 260 (K.B. I80I), the word "children" was construed to mean "heirs of the body." Note 74 supra.

$7^{8}$ Desmond v. MacNeill, go Conn. I42, 96 Atl. 924 (Igr6) (devise was "to A, for herself and her children" and the language was said to force the life estate and remainder construction); Jones v. Jones, 7 Ga. 76 ( 1849 ) (devise of residue "to A, to her personally, individually and exclusively and to her children, and not to her husband"); Cooper v. Mitchell Investment Co., I33 Ga. 769, 66 S.E. I09o (I909) (devise was "to A and her children after her"); Schaefer v. Schaefer, I4I Ill. 337, 3I N.E. I36 (I892) ("to A for her sole use and benefit and of her children thereafter"); Downes v. Long, 79 Md. 382, 29 Atl. 827 (I894) (court seemed to rely on the fact that the terms of the devise specifically included after-born children); Hannan v. Osborn, 
From time to time various factors have been denied any effect in so far as overcoming the second resolution is concerned. Thus, the fact that the named person is given a power of appointment or sale, ${ }^{79}$ or that a limitation is placed on his power of sale,$^{80}$ or that the interest of the named person is free and clear of her husband's control, ${ }^{8 x}$ or that after-born children are specifically included, ${ }^{8 z}$ or that there is a gift over on default of issue,$^{8_{3}}$ or that the interest of the parent is to go to him only if he takes care of the testator, ${ }^{84}$ are all insufficient to overcome the preference for concurrent ownership on the part of the parent and the children.

\section{SECOND RESOLUTION IN WILD'S CASE REPUDIATED AND THE EFFECT OF ITS REPUDIATION}

In at least two states the second resolution in Wild's Case has been repudiated, and instead of a preference for concurrent ownership between the parent and his children, a preference for an estate for life in the parent with a remainder in the children has been established.

One of these states is Kentucky. Kentucky first repudiated the second resolution in connection with devises by the testator to his wife and their children, because to give the wife an interest in fee simple in part of the land devised in such cases frequently resulted in the property passing out of the blood of the testator. On the other hand, if the wife is given only an estate for life with a remainder to the children of the testator, this possibility is avoided. From cases of this type, Kentucky extended the repudiation to other situations in which the property would pass out of the blood

${ }_{4}$ Paige (N.Y.) 336 (1834) (devise was "to A to have and to hold the same to her and her chil. dren forever"); Coakley v. Daniel, 57 N.C. 90 ( $185^{8}$ ) (devise was "to A as a loan for the benefit of $A$ and her children"). In Bowers v. Bowers, 4 Heisk. (Tenn.) 293 (187r), the devise was "to $A$, to have and to hold the same to her and her children for their special use and benefit forever," and the court said that A took the fee simple title in trust for herself and children and on her death the children would take the legal title in fee simple.

79 Dryer v. Crawford, 90 Ala. I3I, 7 So. 445 (I889); McCord v. Whitehead, 98 Ga. 38I, 25

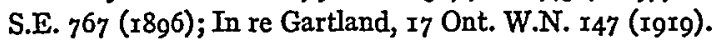

8o Kelly v. Kelly, 176 Ark. 548, 3 S.W. (2d) 305 ( 1928 ).

${ }_{8 x}$ New England Mortgage Security Co. v. Gordon, 95 Ga. 78I, 22 S.E. 706 (I894); McCord v. Whitehead, $98 \mathrm{Ga} .38 \mathrm{I},{ }_{5}$ S.E. 767 (1896). But cf. Froggatt v. Wardell, 3 De G. \& S. 685 (I850).

${ }_{82}$ Reddoch v. Williams, I29 Miss. 706, 92 So. 83 (r922); Belote v, White, 39 Tenn. 703 (1859); Smith v. Smith, I08 Tenn. 21, 64 S.W. 483 (I9OI); Houston v. Schuhmann, 92 S.W. (2d) 1086 (Tex. Civ. App. I936); Oates v. Jackson, 2 Str. II72 (K.B. I742). But cf. Downes v. Long, 79 Md. 382, 29 Atl. 827 (1894).

$8_{3}$ Cormack v. Copous, 17 Beav. 397 (Rolls Ct. 1853 ). But cf. Hood v. Dawson, 98 Ky. 285 , 33 S.W. 75 (1895).

84 In re Utz's Estate, 43 Cal. 200 (I872). 
of the testator, and finally the repudiation became complete when the life estate and remainder construction was adopted even though there was no need of this construction to preserve the property for the testator's own blood relations. ${ }^{85}$

In Pennsylvania, which is the other state that has repudiated the second resolution, the motive was entirely different from the one in Kentucky. The motive was to give a construction to a limitation to a parent and his children that would allow after-born children to share in the devise. The adoption of the second resolution prevents after-born children from sharing in the case of immediate gifts to a parent and his children because of the rule of construction in class gifts that only those members of the class born before the period of distribution can share. ${ }^{86}$ Even if the gift to the parent and his children is postponed to some period subsequent to the date the will takes effect, so that children born at any time before the end of the postponed period can share in the gift, those born thereafter are excluded by the combination of the second resolution and the rule of construction as to the period of time during which a class can increase its membership. ${ }^{87}$ The life estate and remainder construction adopted in Pennsylvania, however, normally assures the inclusion of all after-born children because the class can increase in membership until the end of the

${ }^{85}$ In the following cases the life estate and remainder construction was necessary to keep the property in the blood relations of the testator: Koenig v. Kraft, $87 \mathrm{Ky} .95$ (I888); Brand v. Rhodes Adm'r, I7 Ky. L. Rep. 97, 30 S.W. 597 (I895); Lacey's Exec'r v. Lacey, I70 Ky. I60, I85 S.W. 495 (r9r6); Shelman \& Co. v. Livers' Exec'r, 229 Ky. 9o, I6 S.W. (2d) 800 (I929); cf. Lymn v. Hall, ror Ky. 738, 43 S.W. 402 (r897). In the following cases the life estate and remainder construction was not necessary to keep the property in the blood relations of the testator: Kuhn v. Kuhn, 24 Ky. L. Rep. Ix2, 68 S.W. I6 (rgo2); Haydon v. Layton, I28 S.W. 90 (Ky. C. A. rgro); Burns v. Mosely, I62 Ky. I99, I72 S.W. 52I (IgI5); Harrington v. Layton, $200 \mathrm{Ky} .630,255 \mathrm{~S} . W .27 \mathrm{I}$ (I923). In the following cases special facts justified the life estate and remainder construction: Turner v. Patterson, 35 Ky. 292 (1837); Frank v. Unz, 9I Ky. 62x, I6 S.W. $7 \times 2$ ( $189 x$ ). In the following cases special facts justified the conclusion that the parent and the children should take concurrently: Rice v. Klette, ${ }_{4} 4 \mathrm{Ky}$. 787 , I49 S.W. roIg (r9r2); Hatcher v. Pruitt, 23I Ky. 731, 22 S.W. (2d) I33 (I929). In the following case the parent and the children took concurrently though no special facts were present: Gill's Heirs v. Logan's Heirs, II B. Mon. (Ky.) 23 I (I850). In the following cases special facts justified the conclusion that the parent should take a fee simple estate to the exclusion of the children: Hood v. Dawson, $98 \mathrm{Ky} .285,33$ S.W. 75 (1895); Wilson v. Shumate, $130 \mathrm{Ky}$. 663, II3 S.W. 85 (Ig08) (deed); Naville v. American Machine Co., I45 Ky. 344, I40 S.W. 559 (Igrr); Eakins v. Eakins, x9r Ky. 6r, 229 S.W. I30 (I92I). If the word "children" is construed to mean "heirs of the body" because of special facts, a fee tail estate is created which is converted into a fee simple estate by the local statute: Martin v. Martin, 203 Ky. 7I2, 262 S.W. IOgI ( 1924$)$. Note 95 infra contains a discussion of deeds of land and personalty and bequests of personalty in Kentucky.

${ }^{86}$ Casner, op. cit. supra note 6r, at 272 n. 36 .

87 Ibid., at 275 . 
prior life estate in the parent, which usually is the death of the parent when no more children can possibly be born. ${ }^{88}$

A great deal is to be said for the life estate and remainder construction adopted in Kentucky and Pennsylvania. As has been suggested before, people usually think of parent and children enjoying property successively and not concurrently. Thus, the average testator who employs the phrase "to A and his children" probably has in mind successive enjoyment. Also, he probably intends to benefit all of A's children whenever born. Consequently, the probable intention of the average testator is more likely to be effectuated by the life estate and remainder construction than by the concurrent ownership construction set forth in the second resolution in Wild's Case. ${ }^{89}$

\section{DEEDS OF LAND AND PERSONAITY AND BEQUESTS OF PERSONALTY WHEN THERE ARE CHILDREN}

The wording of the second resolution in Wild's Case confines its application to devises of land. Since, however, the view announced in the second resolution, that the parent and the children take concurrent estates in the property when there are children alive at the date the will takes effect, is a reasonable interpretation of the language employed when other methods of disposition are involved, many courts have adopted the construction preference for concurrent interests between parent and children in inter vivos gifts of land and personalty and bequests of personalty. ${ }^{90}$ The

88 Forest Oil Co. v. Crawford, 77 Fed. 106 (C.C.A. 3 d 1896 ); Haskins v. Tate, 25 Pa. 249 (I855); Estate of I. R. Smith, 9 Phila. 348 (1874); Crawford v. Forest Oil Co., 208 Pa. 5, 57 Atl. 47 (xg04); Elliott v. Diamond Coal \& Coke Co., 230 Pa. 423, 79 Atl. 708 (xgIr); Vaughn's Estate, 23० Pa. 554, 79 Atl. 75० (IgIr) (postponed gift). In Asper v. Stewart, 246 Pa. 25, 92 Atl. $\mathrm{r}_{33}$ ( $\mathrm{rg}_{4}$ ), the court found evidence to justify the conclusion that the word "children" meant heirs of the body, so a fee tail estate was created, which was converted into a fee simple estate by the local law.

${ }^{89}$ The Uniform Property Act, Section I3 $_{3}$, adopts the life estate and remainder construction. Rest., Property $\$ 283$ (Tent. Draft no. II 1939), states the second resolution in Wild's Case as the law.

90 Deeds of land: Sullivan v. McLaughlin, 99 Ala. 6o, II So. 447 (r89I); Moore v. Lee, Io5 Ala. 435 , 17 So. 15 (I894) ("to $A$ and her children forever"); Porter v. Henderson, 203 Ala. 312, 82 So. 668 (I9I9); Higdon v. Leggett, 205 Ala. 437, 88 So. 646 (r921) ("to A and her children and also in trust for such children as may be born of said A"); Loyless v. Blackshear, 43 Ga. 327 (I87I); Chess-Carley Co. v. Purtell, 74 Ga. 467 (1885); Luquire v. Lee, I2r Ga. 624, 49 S.E. 834 (rgo5) (a deed of trust, and $A$ and her children were joint beneficiaries for the life of A); Plant v. Plant, 122 Ga. 763, 50 S.E. 96I (1905); Powell v. James, I4I Ga. 793, 82 S.E. 232 (I914); Medlock v. Brown, I63 Ga. 520, 136 S.E. 55I (I927); Dean v. Long, x22 Ill. 447, I4 N.E. 34 (1887); Albers v. Donovan, 37 IIll. $45^{8}$, 2 I N.E. (2d) ${ }_{563}$ (r939); King v. Rea, $5^{6}$ Ind. I (1877); Glass v. Glass, 7r Ind. 392 (r880); Fountain Coal Co. v. Beckleheimer, Io2 
form of concurrent ownership created today is normally a tenancy in common $^{9 x}$ and as to personalty the concurrent owners take absolutely, and they also take in fee simple the land which is the subject matter of a deed if the magic word "heirs" is no longer necessary to create such estates in inter vivos conveyances. ${ }^{92}$

Additional factors may, of course, overcome the preference for the concurrent ownership construction. Frequently, the additional factors are such as to influence the court to adopt the construction of a life interest in

Ind. 76, I N.E. 202 ( 1885 ); Tucker v. Tucker, 78 Ky. 503 (1880); Bullock v. Caldwell, 8I Ky. 566 (1884); Brann v. Elzey, 83 Ky. 440 ( 1885 ); Brabham v. Day, 75 Miss. 923, 23 So. 578 (1898); Heath v. Heath, II4 N.C. 547 , x9 S.E. I55 (1894); Darden v. Timberlake, I39 N.C. I8I, 5I S.E. 895 (rgo5); Cullens v. Cullens, I6r N.C. 344 , 77 S.E. 228 (I9I3) ("to A and her children forever" created concurrent estate for life because the magic word "heirs" not used); Buckner v. Maynard, Ig 8 N.C. 802 , I 53 S.E. $45^{8}$ (I930); Sheets v. Mouat, 5 Ohio N.P. (N.S.) 22 (I907); Shirlock v. Shirlock, 5 Pa. 367 (I847); Sease v. Sease, 64 S.C. 216, 4 I S.E. 898 (IgO2); Reeves v. Cook, 7 I S.C. 275, 5 I S.E. 93 (Ig04); Porter v. Lancaster, 91 S.C. 300 , 74 S.E. 374 (IgI2); Arrington v. Roper, 3 Tenn. Ch. 572 (1877) ("to A and such children as she now has or may hereafter have"); Livingston v. Livingston, I6 Lea (Tenn.) 448 (I886); Norton v. Reed, 42 S.W. 688 (Tenn. Ch. App. 1897); Yarbrough v. Whitman, 50 Tex. Civ. App. 39I, I10 S.W. 47 (Ig08); Eves v. Blazewich, I24 Wash. 2Ir, 2r3 Pac. 936 (I923); see Beauchamp v. Fitzpatrick, $\mathrm{I}_{33}$ Ga. 4I2, 65 S.E. 884 (rgo9). In Williams v. Williams, I6 Lea (Tenn.) 164 ( 1885 ), the deed was to the grantor's wife and use of his children, for her sole and separate use, together with his children, free from his debts and contracts; she to have control of the property, and in the event of her death before his own, the property was to revert to him in trust for his children. The court held the wife and children were concurrent beneficiaries during the liftime of the wife and then the children took the entire interest absolutely; to the same effect is Hammock v. Martin, ${ }_{47}$ Ga. 828, 95 S.E. 679 (19I8) (deed was "to sole use of my wife, $\mathrm{A}$, while in life and her children by me begotten"). Deeds of personalty: Berry $\mathrm{v}$. Hubbard, 30 Ala. I9I (1857); Gay v. Baker, 58 N.C. 344 (1860). Bequests of personalty: Dunn v. Bank of Mobile, 2 Ala. I52 (r84r) ("to A and her children then in life and thereafter to be born"); Vanzant v. Morris, 25 Ala. 285 (1854) (postponed); Moore v. Ennis, ro Del. Ch. I70, 87 Atl. I009 (Igr3); Jackson v. Coggin, 29 Ga. 403 (1859); Hoyle v. Jones, 35 Ga. 40 (I866); Allen v. Claybrook, 58 Mo. I24 (1874); Mason's Exec'rs v. Trustees of Methodist Episcopal Church of Tuckerton, 27 N.J. Eq. 47 (1876); Armstrong v. Moran, I Bradf. (N.Y.) $3^{14}$ (1850); Davis v. Cain's Exec'r, 36 N.C. 304 (1840); Gannaway v. Tarpley, I Cold. (Tenn.) 572 (I860); Cannon v. Apperson, 82 Tenn. 553 (I885); Gordon v. Whieldon, II Beav. I70 (Rolls Ct. 1848 ); see Nimmo v. Stewart, 2 I Ala. 682 (I852); Bull v. Bull, 8 Conn. 47 (I830); Bowers v. Bowers, 5 I Tenn. 293 (1871). In Mason v. Clarke, $x_{7}$ Beav. x26 (Rolls Ct. r853), the named parent was enceinte at the time the will was drafted and the child born later died before the testator. The court held that the parent took the legacy absolutely. To the same effect is Davis v. Sanders, I23 Ga. I77, 5I S.E. 298 (I905).

${ }_{95}$ Note go supra. In the following cases, however, the parent and his children took a joint tenancy: deeds of land, Tucker v. Tucker, $78 \mathrm{Ky} .503$ ( 1880 ); Brann v. Elzey, $83 \mathrm{Ky} .440$ (1885); bequests of personaliy, Jackson v. Coggin, 29 Ga. 403 (I859); Gordon v. Whieldon, II Beav. I7o ( 1848 ); see Nimmo v. Stewart, 2r Ala. 682 ( $\left.185^{2}\right)$.

92 I Rest., Property $\$ 27$ (I936). See Cullens v. Cullens, $16 x$ N.C. 344,77 S.E. 228 (Igr3) (the deed created only life estates because the word "heirs" was not used). 
the parent with a remainder in the children. ${ }^{93}$ Sometimes the additional evidence causes the word "children" to be construed as a word of limitation like the word "heirs," and an absolute interest in the parent is thereby created. 94

93 Deeds of land: Hubbird v. Goin, ${ }_{37} 7$ Fed. 822 (C.C.A. 8th 1905) (expressed intention was to benefit parent during her lifetime, and also court thought desire was to benefit after-born children); May v. Ritchie, 65 Ala. 602 (I880) (deed created a trust in favor of "A and her children, for their support and support of her children and after her death then to her children"); Pearre v. McDonald, 168 Ga. 752, I49 S.E. 44 (I929) (deed was "to A and her children after her"); Seymour v. Bowles, $x_{72}$ IIl. 521, 50 N.E. x22 ( 1898 ) (if any child died without issue his share was to go to the "surviving children," and this was thought sufficient to force the adoption of the life estate and remainder construction); Fullagar v. Stockdale, I $_{3} 8 \mathrm{Mich}$. 363 , Ior N.W. 576 ( 1904 ) (the life estate and remainder construction was adopted to keep the property in the blood of the grantor); Kinney v. Mathews, 69 Mo. 520 (1879) (deed "to A and her children then born and afterwards to be born," court held that intention to include afterborn children could be given effect only by life estate and remainder construction); Blair v. Osborne, 84 N.C. 417 ( 1881 ) (the language of the deed was said to force the life estate and remainder construction; the deed read "to $A$ to have and hold to her and the children begotten of B forever"); Beecher v. Hicks, 7 Lea (Tenn.) 207 (I88I) (the deed was "to A for her sole and separate use and benefit, and free from all debts, liabilities and contracts of her husband," and to the children of said A "upon her body begotten by her said husband," and court relied principally on the language); Gibbs v. Barkley, 242 S.W. 462 (Tex. I922) (the granting clause was "to A and her children" and the habendum clause was "to A for life and at her death to the issue of her body"); Talley v. Ferguson, 64 W.Va. 328, 62 S.E. 456 (Igo8) (deed to grantor's son's wife and children, and since provision was obviously made for son's family, the grantor must have intended to include after-born children; to bring about their inclusion the life estate and remainder construction adopted). In Chenery v. Stevens, 97 Mass. 77 (1867), the deed was "to $A$ and her children and to their heirs and assigns and $A$ is to have the exclusive control of the premises and the income thereof for her own support and use during her natural life," and there were six children of A at the date of the deed. The court held that A took an undivided one-seventh in fee simple and a life interest in the other six-sevenths. Deed of personalty: Elmore v. Mustin, $28 \mathrm{Ala}$. $3^{\circ} 9$ ( $\left.185^{6}\right)$ (deed was "to A and to her children at her death"). Bequest of personalty: Noe's Adm'r v. Miller's Exec'r, 3I N.J. Eq. 234 (1879) (bequest was "to A, her husband not to have any control of said legacy, but to be hers and her child's or children's forever"); Ward v. Grey, 26 Beav. 485 (Rolls Ct. 1859) (only additional factor was that the parent had a power to appoint among the children). Consider Berry v. Hubbard, 30 Ala. I9I ( 1857 ), in which a deed of personalty was made "to A during her natural life and to her children," and the court held A and the children took concurrently with A's interest confined to a life interest.

94 Echols v. Jordan, 39 Ala. 24 ( 1863 ) (bequest "to A to her and her children forever," and A had one child at the testator's death; the court held that "children" meant "heirs of the body" and so an absolute interest created in the parent as to personalty); Moore v. Simmons, 2 Head (Tenn.) 545 (1859) (deed included both realty and personalty and general plan showed an intent to give an absolute interest to the parent); Wallace v. Dold's Exec'rs, 30 Va. $25^{8}$ ( $183 \mathrm{r}$ ) (the general scheme of the will caused the court to give the parent an absolute interest; a bequest was involved); Conrad v. Conrad's Exec'rs, I23 Va. 7rr, 97 S.E. 336 (IgI8) (the bequest was "to A for the benefit of herself and our children," and A took to the exclusion of the children). In Palmer v. Atwood, I88 Ga. 99, 3 S.E. (2d) 63 (I939), the deed of land was to grantor's wife and her children for life and court recognized that the specification that the estate was for life prevented any possibility of a finding that an estate tail was intended. 
In at least two states the constructional preference is for a life interest in the parent with a remainder in the children. One of these states is Kentucky, in which the life interest and remainder construction was originally adopted to keep the property in the blood of the transferor but later was extended to other situations where the concurrent ownership construction would not increase the probability of the property passing out of his blood. ${ }^{95}$ The other state is Pennsylvania, where the basis of the adoption of the life interest and remainder construction is the belief that after-born children should be included, and their inclusion is accomplished with the least inconvenience by giving the children a remainder which can increase as to its membership until the termination of the life interest in the parent. ${ }^{96}$

In Tygard v. Hartwell, 97 the named parent was given an estate in fee simple when a deed was made to the parent and his children, and there were children living at the date the deed took effect. The reason given was that if the grantor had intended the living children to take as tenants in common with the parent, he would have named them. This is in effect a repudiation of the constructional preference for concurrent ownership in

9s Deeds of land: In the following cases the life estate and remainder construction tended to preserve the property for the blood of the grantor or the person who furnished the consideration if a purchase was involved: Davis v. Hardin, 80 Ky. 672 (r880); Smith v. Upton, I2 Ky. L. Rep. 27, r $_{3}$ S.W. 72 I (r89o); Bowe v. Richmond, 33 Ky. L. Rep. r73, rog S.W. 359 (Igo8); Virginia Iron Coal \& Coke Co. v. Dye, I46 Ky. 519, I42 S.W. I057 (I912); Scott v. Scott, $x_{72}$ Ky. 658, Igo S.W. 143 (I9I6); Hicks v. Jewett, 202 Ky. 6r, 258 S.W. 934 (I924). In the following cases the life estate and remainder construction had no tendency to keep the property in the blood of the grantor or purchaser: Hall v. Wright, I2I Ky. I6, 87 S.W. II29 (I905); Brumley v. Brumley, 28 Ky. L. Rep. 23I, 89 S.W. I82 (Ig05); Ramey v. Ramey, I95 $\mathrm{Ky} .673,243$ S.W. 934 (1922). In the following cases the named parent paid the purchase price, and the life estate and remainder construction was adopted: McFarland v. Hatchett; II8 Ky. 423, 80 S.W. rr85 (I904); Sayler v. Johnson, 32 Ky. L. Rep. 709, ro7 S.W. 2 10 (Ig08); Ewing v. Millikin, I $48 \mathrm{Ky} .837$, I48 S.W. II (rgI 2 ). In the following cases additional factors were relied on in adopting the life estate and remainder construction: Webb v. Holmes, $3 \mathbf{B}$. Mon. (Ky.) 404 (r843); Bodine's Adm'r v. Arthur, 9I Ky. 53, I4 S.W. 904 (r890); Goodridge v. Goodridge, 9I Ky. 507, I6 S.W. 270 (I89I); Baker v. Baker, I9I Ky. 325, 230 S.W. 293 (I921); see Rogers v. Payne, I4 B. Mon. (Ky.) I67 (I853); cf. Tucker v. Tucker, $78 \mathrm{Ky}$. 503 (I880); Bullock v. Caldwell, 8I Ky. 566 (I884); Brann v. Elzey, 83 Ky. 440 (1885).

Additional factors justified the conclusion that the named parent took an estate in fee simple in Viley v. Frankfort \& Cincinnati R. Co., 2x Ky. I. Rep. 255, 5I S.W. x73 (1899) and Wilson v. Shumate, r3o Ky. 663, II3 S.W. $85^{1}$ (rgo8). If the wording of the deed is such that at common law an estate tail would have been created though children were living, as for example "to A and the heirs of his body," a fee tail estate is still created in Kentucky and the local statute converts the same into an estate in fee simple unless the language indicates that the words "heirs of the body" mean children in the particular limitation: Lawson v. Todd, I29 Ky. I32, IIO S.W. 4 I2 (r908).

${ }_{96}^{6}$ Deeds of land: Coursey v. Davis, 46 Pa. 25 (I862); Hague v. Hague, I6I Pa. 643, 29 Atl. 26I (I894); cf. Shirlock v. Shirlock, 5 Pa. 367 (1847).

97204 Mo. 200, I02 S.W. 989 (rg07). 
the parent and children and the substitution of a doctrine that the parent takes absolutely.

Here, again, the writer desires to endorse the life interest and remainder construction as adopted in Kentucky and Pennsylvania because of the probability that the average transferor intends successive rather than concurrent ownership between parent and children, and, also, he very likely intends all children whenever born to share in the gift. The constructional preference adopted should give effect to these more likely desires. ${ }^{98}$

VIII. DISPOSITIONS IN FAVOR OF SEVERAC NAMED PARENTS AND THEIR CHIIDREN WHEN SOME HAVE CHILDREN AND

SOME DO NOT

When a gift is made in favor of several named persons and their children and some have children and some do not at the date the dispositive instrument takes effect, the first problem to decide is whether the limitation should be construed as making separate gifts to each parent and his children. If this construction is adopted, the problem should be solved in accordance with the previous discussion. If the gift to each parent and his children is construed separately, the same language may mean different things, depending on whether there are or are not children.

In most cases which have considered this complex problem, the courts have adopted the same construction for all the parents and their children, and that construction has been life interests in the parents with remainders in the children. ${ }^{99}$ This result obviously is motivated by a desire to give the children born later an equal chance to share with the children already born, and the life interest and remainder construction makes this possible with the least inconvenience.

In one case ${ }^{\mathrm{roo}}$ where the limitation was "to $\mathrm{A}$ and her children and $\mathrm{B}$ and his children as long as they live" and A had children living, but B did not, the court held that $A$ and her children and $B$ took to the exclusion of afterborn children of $A$ and $B$. A result which allows the living children to share concurrently with the named parents and excludes completely the children who may be born to the parent who as yet has no children seems to be the least desirable of the possible results.

${ }_{98}^{8}$ The Uniform Property Act, Section I3, adopts the life estate and remainder construction. The Restatement of Property $\$ 283$ (Tent. Draft no. Ir 1939), states as the law the preference for concurrent ownership.

${ }^{99}$ Bridgers v. Wilkins, $5^{6}$ N.C. 342 ( 1857 ) (some reliance was placed on the fact that the husbands were specifically excluded); Shepard v. Shepard, 60 Vt. 109, I4 Atl. 536 (1887) (there was a provision that if anyone died without children the others were to take that share); cf. Coakley v. Daniel, 57 N.C. 90 ( $\left.185^{8}\right)$.

${ }^{100}$ Robinson v. Harris, 73 S.C. 469,53 S.E. 755 (1906). 
In another case, ${ }^{\text {xor }}$ the gift was to the testator's two sons, $A$ and $B$ "and their children an undivided one-half interest to each." A had no children at the testator's death and B did have children. The court held that the intention of the testator as disclosed by the language of the gift was to benefit each son personally to the same extent. The first resolution in Wild's Case was applied to the gift to A, creating in him a fee tail estate which in turn was converted into a fee simple estate, and the same construction was given to the gift to $\mathrm{B}$, so that $\mathrm{A}$ and $\mathrm{B}$ would be treated exactly alike.

\section{CONSTRUCTIONS WHICH RESULT IN THE CREATION OF A CLASS} GIFT WHEN THE GLTT IS TO A PARENT

\section{AND HIS CHILDREN}

When a gift is made to a parent and his children, no class gift is created and no class-gift problems are presented if the word "children" is construed as a word of limitation rather than a word of purchase because under such circumstances the only beneficiary is the named parent. The degree of ownership he receives turns on whether the word "children" is deemed synonymous with the word "heirs," in which case he has a fee simple estate or its equivalent in personalty, or with the words "heirs of the body," in which case he has a fee tail estate, which in turn may be changed to something else by the local statute on entails. ${ }^{\text {102 }}$ We have seen from the previous discussion that the word "children" is construed as a word of limitation synonymous with the words "heirs of the body" when the first resolution in Wild's Case is applicable. ${ }^{\mathbf{1 0 3}}$ Otherwise, it is deemed a word of purchase unless additional factors disclose a different intention in the particular case. ${ }^{\text {To4 }}$

Whenever the word "children" in these cases is used as a word of purchase, the limitation to them, at least, is to an entity or a unit and is clearly a class gift. The more difficult problem to decide is whether the named parent is also to be deemed a part of the entity, so that the gift is to one class composed of the parent and the children, or whether the gift to the parent is to be deemed a separate gift to an individual so that there is in fact a gift to an individual and a class. Clearly if the life interest and remainder construction is adopted, the named parent is not a member of

${ }^{10 x}$ Knight v. O'Brien, 202 Ala. 440, 80 So. 824 (1919).

${ }_{102}$ If the local statute on entails converts the fee tail estate into a life estate in the first taker with a remainder to the heirs of his body, a class-gift problem may arise with respect to the remainder created by the statute.

${ }^{103}$ Cases dealing with the first resolution in Wild's Case are collected in note 2 supra.

${ }^{304}$ Cases in which the word "children" was construed as a word of limitation other than under the first resolution in Wild's Case are collected in notes 25, 77 and 94 supra. 
the class. ${ }^{\text {ros }}$ When some other construction is adopted, whether we should say the named parent and his children take as one unit should be postponed until after we examine several situations.

First, suppose an immediate gift is made "to A and his children" and there are no children at the date the dispositive instrument takes effect and there never have been any. Suppose further that the first resolution in Wild's Case is not applied either because it has been repudiated, or because the subject matter of the gift is personalty or because the dispositive instrument is a deed. We have seen that under these circumstances the courts which have not adopted the life interest and remainder construction have held that A takes all the property to the exclusion of after-born children, and he takes it absolutely, unless land is involved and some formula is still required to create a fee simple estate. ${ }^{x 06}$ Could such result be reached without at the same time admitting that the gift was to one unit composed of the parent and his children? Probably not without doing some violence to an already established rule of construction in the field of class gifts which is that, if there are no members of the class in existence at the period of distribution, all members of the class whenever born are entitled to share..$^{107}$ Thus, if the gift "to A and his children" was a gift to an individual and a class, since no members of the class are in being under the above suppositions, all children whenever born should share. The result actually reached, however, which allows A to take to the exclusion of children born later, is entirely consistent with the class-gift doctrine that closes the class on the period of distribution if we treat $\mathrm{A}$ as a member of the class. ${ }^{108}$

If the gift "to A and his children" in the above-suggested case is postponed until the termination of a prior life interest, the inclusion in the gift of children born after the dispositive instrument takes effect and prior to the termination of the life interest does not throw any light on whether the gift is to an individual and a class or just to one class including the parent and the children because under either construction such after-born children are included. ${ }^{\text {ros }}$

sos Cases in which the life estate and remainder construction was adopted are collected in notes $26,4 \mathrm{r}, 45,49,78,85,88,93,95,96$ and 99 supra.

${ }^{106}$ Cases which hold that the parent takes absolutely when there are no children are collected in notes 36,44 and 47 supra. To the effect that after-born children are excluded are Robinson v. Harris, 73 S.C. 469 , 53 S.E. 755 (1906); Martin v. Martin, 52 W.Va. 381, 44 S.E.I98 (1903). To the effect that they are included if there is an express manifestation of intention to include them are Boehm v. Baldwin, 22I Ill. 59, 77 N.E. 454 (Igo6); Mitchell v. Long, 80 Pa. 516 (1876). But cf. Davis v. Hollingsworth, $\mathrm{II}_{3}$ Ga. 210, 38 S.E. 827 (Igor) (deed); Bank of Graymont v. Kingery, I7o Ga. 77r, I54 S.E. 355 (r930) (deed); Kinney v. Mathews, 69 Mo. 520 (1879) (deed).

so7 Casner, op. cit. supra n. 6r, at 270 n. 3I. $\quad$ to8 Ibid., at 268.

${ }^{209}$ Ibid., at 275. Consider also Vanzant v. Morris, 25 Ala. 285 ( 1854 ), and the cases cited in note IIr infra. 
Second, suppose a gift is made "to A and his children" and there are children alive at the date the dispositive instrument takes effect. The adoption in such case of the concurrent ownership construction may make it essential to decide whether the gift is to an individual and a class or to one class including the parent and the children.

The fact, however, that the problem presented is the inclusion of afterborn children does not make such decision necessary because they are excluded in either case if the gift to the parent and his children is immediate, ${ }^{\text {Iro }}$ and are included in either case if the gift is postponed and they are born before the end of the postponed period. ${ }^{\text {Irr }}$

If the problem presented is the division of the subject matter of the gift, is it necessary to decide whether the gift is to one entity composed of the parent and his children or to an individual and an entity? The possible methods of division are: the parent, one-half, and the children, onehalf, or a per capita division among the parent and the children so that the size of the share the parent gets depends on the number of children there are to share in the gift. The latter construction clearly predominates as can be gathered from the cases where the issue presented is the size of the share of each taker ${ }^{\mathrm{Tr} 2}$ and also can be deduced from the presumption

rro Where there is an immediate gift, children born after the dispositive instrument takes effect are excluded: Devises of land, Biggs v. McCarty, 86 Ind. 352 (I882); Coogler v. Crosby, 89 S.C. $508,7_{2}$ S.E. I49 (x9xI); bequest of personalty, Moore v. Ennis, ro Del. Ch. I7o, 87 Atl. roog (I9I3); Coogler v. Crosby, 89 S.C. 508, 72 S.E. I49 (IgIr); deed of land, Moore v. Lee, I05 Ala. 435, I7 So. I5 (I894); Porter v. Henderson, 203 Ala. $3 \times 2,82$ So. 668 (IgIg); Plant v. Plant, I22 Ga. 763, 50 S.E. 961 (I905); King v. Rea, 56 Ind. I (I877); Glass v. Glass, 7 I Ind. 392 (1880); Cullens v. Cullens, I6I N.C. 344,77 S.E. 228 (I913) (gift actually postponed but no children were born until after the end of the postponed period); Sheets v. Mouat, 5 Ohio N.P. (N.S.) 22 (I907); Porter v. Lancaster, 9I S.C. 300,74 S.E. 374 (I912); Livingston v. Livingston, I6 Lea (Tenn.) 448 (I886); deed of personalty, Gay v. Baker, 58 N.C. 345 (I860). Child in gestation at the date the dispositive instrument takes effect is included: Medlock v. Brown, 163 Ga. 520, I36 S.E. 55 I (r927) (deed); King v. Rea, 56 Ind. I (1877) (deed); Biggs v. McCarty, 86 Ind. 352 (I882) (devise); Gay v. Baker, 58 N.C. 345 ( 8860 ); Heath v. Heath' I 14 N.C. 547 , I9 S.E. I55 (I894). Afterborn children included when the intention to include them is expressed: Dunn v. Bank of Mobile, 2 Ala. 152 (I84I) (bequest); Higdon v. Leggett, 205 Ala. 437,88 So. 646 (I92I) (deed); Annable v. Patch, 3 Pick. (Mass.) 360 (I825) (devise and bequest); Reddock v. Williams, I29 Miss. 706, 92 So. 83 I (I922) (devise); Belote v. White, 39 Tenn. 703 ( 1859 ) (devise); Arrington v. Roper, 3 Tenn. Ch. 572 (I877) (deed); Houston v. Schuhmann, 92 S.W. (2d) ro86 (Tex. Civ. App. 1936) (devise); Bently v. Ash, 59 W.Va. 64r, 53 S.E. 636 (Igo6) (devise); cf. Bowers v. Bowers, 4 Heisk. (Tenn.) 293 ( $887 \mathrm{I}$ ). But cf. Davis v. Hollingsworth, II3 Ga. 210, 38 S.E. 827 (Igor) (deed); Bank of Graymont v. Kingery, I70 Ga. 771, I54 S.E. 355 (I930) (deed); Kinney v. Mathews, 69 Mo. 520 (1879) (deed).

Ixx Children born after the dispositive instrument takes effect and before the end of the postponed period are included: Mitchell v. Mitchell, 73 Conn. 303, 47 Atl. 325 (Igo); Way v. Geiss, 280 III. $x_{52}$, Ix7 N.E. 443 (IgI7); Annable v. Patch, 3 Pick. (Mass.) 360 (I825); Smith v. Smith, I08 Tenn. 21, 64 S.W. 483 (IgOI).

Ixz Porter v. Henderson, 203 Ala. 312, 82 So. 668 (I9rg); Lord v. Moore, 20 Conn. I22 (1849); Gordon v. Jackson, 58 N.J. Eq. I66, 43 Atl. 98 (I899); Cullens v. Cullens, I6I N.C. 344, 77 S.E. 228 (I9I3); Norton v. Reed, 42 S.W. 688 (Tenn. Ch. App. I897); Yarbrough v. 
that the concurrent owners take as tenants in common where the assumption is that each tenant in common takes an equal share unless a contrary intent is manifested. ${ }^{\mathrm{Ir}}$ This prevailing doctrine as to the division of the subject matter does not, however, conclusively prove that the gift is to one entity composed of the parent and his children. True, it is consistent with the view, but it does not compel that view. Even though the gift to the named parent is looked upon as a separate gift to an individual, the size of his share can be made dependent on the number of children there are to share in the gift. Likewise, the adoption of the other view that gives the parent one-half and the children one-half of the subject matter is consistent with either a gift to one entity composed of the parent and the children or to an individual and a class, because the size of the shares of all class members does not necessarily have to be the same. ${ }^{\text {II4 }}$ Thus, the solution of the division problem does not conclusively solve the problem under discussion.

The type of problem which really necessitates a decision on the question whether the gift is to an individual and a class or to one class composed of the parent and his children is where either the parent or all the children, one or the other, but not both, fail to survive the date the instrument takes effect if it is a will, or have their shares revoked if it is a will, or fail to fulfill a requirement of survival to some designated date subsequent to the date the dispositive instrument takes effect. In such cases in the absence of an applicable lapse statute the entire subject matter of the gift goes to the one who is not so disqualified if the gift is to one entity, but there is a lapse as to the share of the one disqualified if it is a gift to an individual and a class. The existent decisions are not sufficiently numerous and uniform to justify the formulation of any rule of construction one way or the other in such cases. ${ }^{\mathrm{xr} 5}$

Whitman, 50 Tex. Civ. App. 39r, 1 10 S.W. 47 I (r9o8); Wills v. Foltz, 6r W.Va. 262, 56 S.E. 473 (1907). If the gift is to husband and wife and their children, the husband and wife take just one share together as tenants by the entireties and each child takes a share equal in size to the amount received by the husband and wife together: Hall v. Stephens, 65 Mo. 670 (1877); Darden v. Timberlake, I39 N.C. $18 \mathrm{r}$, 5 I S.E. 895 (I905); Gordon v. Whieldon, xI Beav. I7o (Rolls Ct. I848). Contra: Hampton v. Wheeler, 99 N.C. 222 (1887) (each parent took share equal to that received by each child).

${ }_{113}$ Cases which hold that the parent and the children take as tenants in common are collected in notes 58 and 90 supra. The second resolution in Wild's Case obviously compels an equal division between the parent and all the children because the concurrent ownership set up in that resolution was a joint tenancy and to have a joint tenancy there must be unity of interest as to all the joint tenants.

114 Estate of Henderson, I6I Cal. 353, IIg Pac. 496 (Igrx); Martin v. Trustees of Mercer University, $98 \mathrm{Ga} .320$, 25 S.E. 522 (1896); In re Ives, 182 Mich. 699, I48 N.W. 727 (1914); Robinson v. McDiarmid, 87 N.C. 456 (I882).

sis Parent dies before the testator and the children take all the subject matter of the devise: Drummond v. Lynch, 82 F. (2d) 806 (C.C.A. $5^{\text {th }}$ I936) (there was, however, an express pro- 
The writer is of the opinion that the inferences deducible from a gift to one entity in these cases are more likely to express the real desires of the average transferor once we decide that the gift to the parent and the childrev is to them concurrently. The close relationship between the beneficiaries serves to draw them together as one unit, and the fact of naming the parent should not serve to separate him from the natural entity the beneficiaries form. ${ }^{\mathrm{Ix} 6}$

\section{DRAFTING}

The moral of this paper is never never describe the beneficiaries of any disposition of property by the words "A and his children" or phrases that are equivalent. No matter what you may conclude the transferor desires when he tells you he wants to benefit a named person and his children, you do not assure the accomplishment of his desires by the language quoted above.

A thorough questioning of the transferor will normally disclose that he has in mind one of three plans in speaking of a parent and his children as the objects of his affection. When the plan is ascertained, the method of its effectuation is usually quite apparent.

The transferor may intend to confine the benefit to the children to that which they receive by descent from their parent. In such case his'reference to the children is natural because he expects them to benefit through the gift to their parent, but at the same time when he is questioned, he discloses that the control of the parent during his lifetime is to be undiminished. When such is the case, the gift should provide directly for an estate in fee simple absolute in the parent or, under some circumstances what may be better still, a life interest in the parent with full and complete power to dispose of an absolute interest by deed or will to anyone and the property remaining at his death to go by way of remainder to his children.

vision for survivorship); Hipburn v. Winthrop, 83 F. (2d) 566 (App. D.C. I936) (there was, however, an express provision for survivorship); Buffer v. Bradford, 2 Atk. 220 (Ch. I74I). Parent dies before the testator and his share lapses: Gordon v. Jackson, $5^{8}$ N.J. Eq. 166, 43 Atl. 98 ( 1899 ) (this result reached even though the size of the share that lapsed was held to depend on the number of children); see Robinson v. Harris, 73 S.C. 469,53 S.E. 755 (Ig06). All the children die before the testator and the parent takes all the subject matter of the devise: Davis v. Sanders, I23 Ga. I77, 5I S.E. 298 (Ig०5); Mason v. Clarke, I7 Beav. I26 (Rolls Ct. 1853). There is a dictum in In re Russell, $x 68$ N.Y. $x 69,6 x$ N.E. $x 66$ (Igor), to the effect that a gift to a parent and her children is not a class gift.

${ }^{1 \times 6}$ The Restatement of Property $\S 283$ (a) (Tent. Draft no. Ir 1939), states that the named parent and the children form one class when there are children at the time the conveyance takes effect. 
The transferor may desire to place the children on an equal footing with the designated parent, in other words, to make them concurrent owners of the subject matter of the gift. Such desire should be spelled out completely by a statement that $A$ and his children are to enjoy the property concurrently as tenants in common and not as joint tenants. Furthermore, the period of time during which later-born children are to be allowed to share in the gift, the extent to which illegitimate and adopted children are to be included, the effect to be attributed to the death or other disqualification of any child or of the named parent before distribution, and the exact size of the share each taker is to receive must be unambiguously stated. Finally, any possibility of the application of the first resolution in Wild's Case should be negatived by an exact statement of the effect if, at the date the devise takes effect, there are no children then in existence. If the dispositive instrument is a deed, and after-born children are to be included, care must be taken to avoid the doctrine that an immediate gift to unborn grantees is invalid. This can be accomplished through the interposition of a trustee to hold the legal title until all the children are born.

Lastly, the questioning of the transferor may disclose that his desire is to benefit the parent and the children successively and not concurrently; that is, that the parent is to enjoy the property for his lifetime, and then the children are to take as purchasers the entire subject matter of the gift. Such a plan requires I) a clear manifestation of intent to confine the interest of the parent to a life interest in the entire subject matter of the gift; 2) care (especially when the life interest in the parent ends other than by his death) in drafting the remainder interest in the children to define the content of the word "children" as to the inclusion of illegitimate children, adopted children and grandchildren, and after-born children; and 3) a clause stating the effect of the death of a child before the period of distribution.

The cases cited in this article involving dispositions "to A and his children" or the equivalent cover a wide range both from the standpoint of geography and of time. That transferors' desires should be subjected to the possibility of frustration and that valuable time of the courts should be taken up in litigation over the meaning of such language seems inexcusable. The extent to which lawyers have been employed to draft the instruments in which such language appears is not known. That they have drafted many of them is a reasonable guess, but a sad commentary. Fortunately for the draftsman, most disputes arise after the employer is dead, and in the heat of the squabble that ensues, the contestants are too busy to take him to task. 